\title{
Pengaruh Kekohesifan, Gaya Kepemimpinan dan Budaya Kerja Terhadap Efektivitas Organisasi
}

\author{
Bambang Dwidjo Kustoro \\ Dosen Fakultas Teknik, Universitas Negeri Jakarta, E-mail :bambangdwidjokustoro@yahoo.co.id
}

\begin{abstract}
Abstrak: Obyek penelitian adalah untuk meneliti pengaruh kekohesifan, gaya kepemimpinan, budaya kerja, daya saing terhadap efektivitas organisasi. Penelitian dilaksanakan pada perusahaan pengadaan alat-alat teknik pendidikan dengan mempergunakan metoda Path Analysis untuk membuktikan hipotese. Dilakukan pada 417 perusahaan yang diwakili oleh 120 sampel dan setiap sampel diwakili oleh direktur yang ditunjuk oleh perusahaan atau oleh pemilik perusahaan dalam menjawab instrumen penelitian berupa questioinaires. Penelitian membuktikan; terdapat pengaruh positif langsung kekohesifan terhadap budaya kerja, terdapat pengaruh langsung positif kekohesifan terhadap efektivitas organisasi, terdapat pengaruh positif langsung gaya kepemimpinan terhadap budaya kerja, terdapat pengaruh positif langsung gaya kepemimpinan terhadap efektivitas organisasi, terdapat pengaruh positif langsung budaya kerja terhadap efektivitas organisasi, terdapat pengaruh positif tidak langsung kekohesifan terhdap efektivitas organisasi melalui budaya kerja, terdapat pengaruh positif tidak langsung gaya kepeminpinan terhadap efektivitas organisasi. melalui budaya kerja. Hasil penelitian menjelaskan bahwa kekohesifan,gaya kepemimpinan dan budaya kerja adalah varian dari efektivitas organisasi. Sehingga dapat disimpulkan bahwa efektivitas organisasi dapat ditingkatkan dengan mengembangkan kekohesifan, gaya kepemimpinan dan budaya kerja.
\end{abstract}

Kata kunci: penelitian, analisis jalur, kekohesifan, gaya kepemimpinan, budaya kerja, efektivitas organisasi, pengaruh langsung, dan pengaruh tidak langsung.

\begin{abstract}
The research was conducted at educational tools companies to obtain with the effect of cohesiveness, leadership style and organizational culture on organizational effectiveness, by using a survey method with path analysis applied in testing hypothesis. The amount of 417 companies selected by simple random sampling with 120 samples and each sample was represented by its director or owner to fill the data. The research reveals that: 1 ) there is a direct positive effect of cohesiveness on organizational culture; 2 ) there is a direct positive effect of cohesiveness on organizational effectivenes; 3 ) there is a direct positive effect of leadership style on organizational culture; 4) there is a positive direct effect of leadership style on organizational effectivenes; and 5) there is a direct positive effect of organizational culture on organizational effectivenes. Due to this findings it could be drawn that 6 ) there is a indirect positive effect of cohesiveness on organizational effectivenes through organizational culture; and 7) there is an indirect positive effect of ledership style on organizational effectivenes through organizational culture. The result explain that the cohesiveness, leadership style, organizational culture are the variances of organizational effectivenes. Therefore, it implies that the organizational effectivenes can be improved by developing the cohesiveness, leadership style, organizational culture.
\end{abstract}

Key words: .Research, Path Analysis, Cohessiveness, Leadership Style, .Organizational culture, Organizational effectiveness, Direct effect, and Indirect effect

\section{Pendahuluan}

Salah satu tujuan dibentuknya Negara Kesatuan Republik Indonesia, seperti te-lah dimaktubkan dalam Pembukaan Undang-Undang Dasar 1945, adalah untuk mencer-daskan kehidupan bangsa. Hal ini bertujuan agar setiap warga negara: mempunyai jatidiri sebagai seorang warga negara yang berdaulat di tengah-tengah komunitas bang-sa-bangsa dunia; mampu menghadapi setiap tantangan, baik dalam konteks lokal, regional, bahkan internasional; mampu menjaga dan memelihara ketertiban lingkungannya dengan 
baik sehingga keharmonisan hidup bermasyarakat dan bernegara dapat terjaga dengan baik; dan memiliki sikap yang mandiri dalam menangani dan memecahkan masalah yang dihadapinya.

Salah satu cara untuk mencapai tujuan yang sangat luhur tersebut adalah melalui proses pendidikan. Hal ini cukup beralasan sebab fungsi pendidikan nasional, seperti yang diamanatkan dalam Undang-Undang No 20 Tahun 2003 tentang Sistem Pendidikan Nasional Pasal 3, adalah untuk mengembangkan kemampuan dan watak peserta didik serta peradaban bangsa yang bermartabat dalam rangka mencerdaskan kehidupan bangsa. Selanjutnya, dijelaskan bahwa pendidikan nasional bertujuan untuk berkembangnya potensi peserta didik agar menjadi manusia yang beriman dan bertakwa kepada Tuhan Yang Maha Esa, berakhlak mulia, sehat, berilmu, cakap, kreatif, mandiri, dan menjadi warga negara yang demokratis serta bertanggungjawab.

Untuk menjamin efektivitas pencapaian tujuan pendididikan tersebut diperlukan proses pembelajaran yang baik, terencana, dan didukung oleh alat-alat atau media pendidikan yang mampu membantu peserta didik memahami materi yang diajarkan dengan mudah dan bermakna. Melalui alat-alat pendidikan ini, peserta didik dapat melihat langsung objek yang dibahas, baik dalam bentuk tiga dimensi - berupa miniatur atau imitasi objek yang sedang dibahas, maupun dalam bentuk dua dimensi - berupa gambar-gambar. $\mathrm{Hal}$ ini semua bertujuan agar para peserta didik dapat memahami konsep atau gambaran riil dari materi dan objek yang dipelajarinya dengan lebih mudah dan lebih baik.

Alat-alat atau media pendidikan ini, biasanya, tidak disediakan oleh sekolah, melainkan dipasok dari perusahaan atau badan usaha penyedia alatalat atau media pendidikan. Dengan demikian, badan usaha penyedia alat-alat atau media pendidikan ini merupakan salah satu mitra strategis lembaga pendidikan yang sangat penting untuk dipelihara dengan baik. Hal ini cukup beralasan, sebab kehadiran badan usaha ini sangat membantu sekolah dalam meningkatkan pembelajaran yang diselenggarakan di sekolah. Keberadaan alat-alat atau media pendidikan merupakan unsur pelengkap dan penunjang yang sangat penting dalam membantu peserta didik memahami materi yang diajarkan. Melalui alat-alat pendidikan ini, para peserta didik dapat memahami materi pelajarannya secara konseptual dan konsepsual. Dengan demikian, agar pasokan alatalat atau media pendidikan dapat lebih terjamin, badan usaha pemasoknya perlu dipelihara dan memelihara diri dengan baik untuk mencapai tujuan pendidikan yang telah ditetapkan secara optimal.

Berdasarkan hasil kajian pendahuluan ( $p r e-$ liminary study), tidak sedikit dari badan usaha ini yang gulung tikar. Hal ini disebabkan oleh berbagai alasan dan beberapa di antaranya adalah barang-barang yang dimilikinya tidak sesuai dengan kebutuhan lembaga pendidikan; pembayaran oleh pihak lembaga pendidikan sering tertunda; para pegawainya tidak bertahan lama; dan terjadinya percepatan dalam perkembangan teknologi informatika sehingga badan usaha ini memerlukan modal yang cukup banyak agar dapat melengkapi barang-barangnya sesuai kebutuhan lembaga pemasoknya.

Konsekuensi logis dari fenomena di atas, badan usaha alat-alat atau media pen-didikan sering timbul tenggelam dalam percaturan bisnis ini. Padahal, kebutuhan akan alat-alat atau media pendidikan ini cenderung bersifat konstan. Hal ini tentu saja dapat menghambat kualitas proses pembelajaran di sekolah karena alat-alat atau media yang diperlukan tidak tersedia. Salah satu upaya untuk menjaga agar alat-alat atau media pendidikan yang diperlukan sekolah-sekolah tetap terjaga dengan memelihara dan meningkatkan efektivitas lembaga pemasoknya, atau dalam hal ini badan usaha pengadaan alat-alat atau media pendidikan.

Masalah efektivitas organisasi badan usaha pengadaan alat-alat atau media pendidikan ini makin mengedepan dewasa ini karena: tuntutan akan kualitas pembelajaran makin meningkat seiring dengan merosotnya indeks daya saing manusia Indonesia jika dibandingkan dengan masyarakat internasional lainnya; sejalan dengan otonomi sekolah, kebijakan untuk untuk melengkapi alat-alat atau media pendidikan berada langsung di tangan sekolah sehingga prosedur pengadaannya cenderung lebih sederhana; masih sejalan dengan otonomi sekolah, masing-masing sekolah dapat menye- 
diakan alat-alat atau media pendidikan yang berbeda, baik dari jenis maupun jumlahnya, dari sekolah lain; keberadaan teknologi informatika telah memacu sekolah untuk menerapkannya sebagai media pendidikan. Hal ini berarti bahwa di samping ancaman, fakta di atas juga memunculkan sebuah peluang bagi badan usaha pengadaan alat-alat atau media pendidikan untuk dapat berkiprah lebih banyak dalam rangka meningkatkan kualitas pendidikan nasional. Hal ini tentu saja hanya dapat dilakukan jika organisasinya telah berjalan dengan baik dan senantiasa memelihara efektivitas organisasinya.

Berdasarkan uraian di atas, masalah yang akan dikaji dalam penelitian ini dapat diuraikan sebagai berikut: 1) Apakah terdapat pengaruh langsung kekohesifan terhadap budaya kerja? 2) Apakah terdapat pengaruh langsung kekohesifan terhadap efektivitas organisasi? 3) Apakah terdapat pengaruh langsung gaya kepemimpinan terhadap budaya kerja? 4) Apakah terdapat pengaruh langsung gaya kepemimpinan terhadap efektivitas organisasi? 5) Apakah terdapat pengaruh langsung budaya kerja terhadap efektivitas organisasi?

Secara teoritik tujuan penelitian ini adalah menguji kebenaran teori Mullins bahwa faktorfaktor kekohesifan, gaya kepemimpinan dan budaya kerja berpengaruh postif langsung terhdap efektifitas organisasi.

\section{Kajian Literatur \\ Definisi Kekohesifan}

Robbins (2000) menegaskan kekohesifan (cohesiveness) berarti derajat dimana setiap anggota kelompok saling tertarik satu sama lain dan termotivasi untuk tetap bersama dalam kelompok tersebut. Colquitt, Lepine \& Wesson menegaskan kekohesifan sebagai keadaan kelompok yang muncul ketika anggota kelompoknya mengembangkan ikatan emosional yang kuat dengan anggota kelompok dan kelompok itu sendiri. Menurur Wexley dan Yukl kekohesifan adalah tingkat solidaritas antara sesama anggota kelompok dan ketertarikan mereka untuk tetap menjadi anggota kelompok. Senada dengan pendapat sebelumnya, George dan Jones (2002) menegaskan bahwa kekohesifan berarti ketertarikan kelompok kepada para anggotanya.
Melengkapi pendapat sebelumnya, Miner menegaskan bahwa kekohesifan dapat diartikan sebagai hasrat para anggota kelompok untuk tetap berada dalam kelompoknya karena mereka tertarik dengan kelompok tersebut dan para anggotanya.

Berdasarkan pendapat di atas, dapat ditegaskan bahwa kekohesifan berarti kesatupaduan kelompok karena adanya sikap ketertarikan antara satu sama lain dengan kelompoknya dan/atau anggota kelompoknya. Ketertarikan menjadi dasar timbulnya solidaritas di antara individu-individu yang tergabung dalam kelompok tersebut. Jika dikaitkan dengan konteks penelitian ini, kelompok yang dimaksud dalam hal ini adalah kelompok karyawan yang tergabung dalam badan usaha yang diteliti.

Kekohesifan terhadap kelompok

Kekohesifan selalu terkait dengan kelompok. Dengan kata lain, kekohesifan ini tidak berlaku secara individual. Meskipun demikian, individuindividu dapat melihat dan merasakan apakah kelompok sudah kohesif atau sebaliknya. Merujuk pada argumentasi ini, kekohesifan dalam konteks ini dapat dikaji berdasarkan penilaian subjek mengenai keterpaduan antar karyawan di lingkungannya.

Menurut Franzoi (1996), kelompok dapat didefinisikan sebagai dua orang atau lebih yang berinteraksi dan saling mempengaruhi dalam suatu masa, saling tergantung satu sama lain, memiliki tujuan bersama dan juga memiliki identitas kelompok.

Berdasarkan kriteria di atas, kelompok berarti terdiri dari atas individu-individu yang memiliki motivasi untuk bergagung karena mempersepsikan bahwa kelompok tersebut merupakan satu kesatuan yang dapat saling membantu. Kondisi ini membuat mereka dapat memberikan kontribusi kepada anggota kelompok lain sesuai dengan kese-pakatan atau ketidaksepakatan yang telah ditetapkan sebelumnya.

Berdasarkan prosesnya keanggotaan kelompok, menurut Franzoi (1996) dapat dibagi ke dalam lima tahapan, yakni: Investigasi, dimana individu mulai mempelajari kelompok yang akan dimasukinya; Sosialisasi, pada tahapan ini individu 
mulai diterima menjadi anggota kelompok; Pemeliharaan, yang berarti bahwa individu telah diterima menjadi anggota kelompok secara penuh; Resolusi, dimana individu mulai dimarjinalkan; dan Pengingatan (remembrance) yang berarti individu telah resmi memiliki status "mantan anggota".

Menurut Simon (1997) organisasi merupakan sistem perilaku yang kooperatif. Hal ini berarti semua anggota kelompok harus dapat menyesuaikan perilakunya dengan harapan kelompoknya. Konsekuensinya, setiap anggota kelompok harus dapat bekerja sama, berbagi pengetahuan, dan menampilkan perilaku yang diharapkan anggota kelompoknya. Jika semua hal ini terpenuhi, maka kelompok tersebut akan lebih kohesif.

Faktor-faktor determinan yang menentukan kekohesifan kelompok, menurut Robbins (2000)adalah: jumlah waktu yang dilalui bersama; keragaman dan tingkat kesulitan memasuki kelompok tersebut; ukuran besarnya kelompok; jenis kelamin para anggotanya; ancaman pihak luar; dan keberhasilan yang diraih sebelumnya. Mullins (2005) menegaskan bahwa kekohesifan sebuah kelompok dipengaruhi oleh empat dimensi, yakni: keanggotaannnya; lingkungan kerja; organisasi; perkembangan dan kematangan anggota kelompoknya.

Jika pendapat di atas dielaborasi, kohesif atau tidaknya suatu kelompok sangat tergantung pada rentang waktu yang dilewati anggota kelompok tersebut. Dengan kata lain, makin banyak rentang waktu yang dilewati oleh anggota kelompok secara bersama-sama, makin kohesif kelompok tersebut. Di samping itu, tingkat kesukaran memasuki kelompok juga sangat menentukan kekohesifan kelompok. Makin sukar memasukinya, makin kohesif kelompok tersebut. Demikian juga dengan ukuran besarnya kelompok. Makin besar ukuran kelompoknya, makin kohesif kelompok tersebut. Berikutnya, kelompok yang hanya terdiri kaum perempuan saja atau campuran kaum perempuan dan lelaki akan lebih kohesif dari pada kelompok yang hanya terdiri atas kaum lelaki saja. Hal lain, jika kelompok mendapat ancaman dari luar, maka kelompok tersebut akan makin kohesif. Terakhir, jika kelompok tersebut pernah berhasil sebelumnya, maka kelompok tersebut akan lebih kohesif di masa-masa berikutnya.
Salah satu kajian mengenai kelompok menurut Luthans adalah The Schachter Study yang berusaha mengkaji keterkaitan antara kekohesifan kelompok dengan produktivitas kerja lembaga. Temuannya menegaskan bahwa kelompok yang kohesif memiliki implikasi yang sangat kuat terhadap produktivitas kerja lembaganya.

Jika temuan di atas dikaitkan dengan konteks penelitian ini, maka kekohesifan kelompok karyawan pada dasarnya akan berpengaruh terhadap upaya peningkatan produktivitas organisasinya. Hal ini cukup beralasan sebab kelompok yang kohesif memiliki daya yang lebih besar untuk mengubah keadaan menjadi lebih baik. Hal ini sejalan dengan pendapat McShane \& Von Glinow (2005) yang menegaskan bahwa individu yang berasal dari kelompok kekohesifan tinggi selalu termotivasi untuk memelihara keanggotaannya dan membantu kelompoknya agar dapat berhasil secara lebih efektif. Selanjutnya pakar tersebut menegaskan bahwa dibandingkan dengan kelompok yang memiliki tingkat kekohesifan yang rendah, sanggota kelompok dengan kekohesifan yang tinggi lebih banyak memanfaatkan waktu secara bersama, lebih sering berbagi informasi, dan lebih puas satu sama lain. Di samping itu menurut Steven L. McShane and Mary Ann Glinow, mereka saling memberikan dukungan yang lebih baik dalam situasi genting.

Berdasarkan uraian di atas, maka dapat disintesiskan bahwa yang dimaksud dengan kekohesifan dalam penelitian ini dapat disintesiskan sebagai keterikatan antar-anggota karyawan untuk saling tertarik satu sama lain dan termotivasi untuk tetap bersama dalam keterpaduan antar mereka di lingkungan kerjanya yang saling mempengaruhi, saling tergantung serta memiliki tujuan bersama dalam satu identitas kelompok.

\section{Gaya Kepemimpinan}

Menurut Hersey dan Blanchard (2001) kepemimpinan merupakan "the process of influencing the activities of an individual or a group in efforts toward goal achievement in a given situation". Definisi ini mengisyaratkan bahwa kepemimpinan memiliki kriteria; sebuah proses mempengaruhi individu atau kelompok; pengaruh tersebut 
dilakukan untuk mencapai tujuan; proses mempengaruhi ini tergantung pada situasi. Dengan demikian, pengaruh yang dilakukan tidak setiap saat dilakukan sama untuk setiap situasi, namun tergantung pada situasinya.

Pendapat lain, Robbins (1997) mengatakan kepemimpinan merupakan proses individuindividu mempengaruhi, dengan tindakan mereka, memfasilitasi pergerakan sekelompok orang ke arah pencapaian tujuan yang telah disepakati. Sedangkan, Griffin (1997) memandang kepemimpinan ini dari dua sudut pandang yang berbeda, yaitu dari sudut proses, yang berarti penggunaan pengaruh yang tidak memiliki kekuasaan memberikan sanksi untuk membentuk tujuan kelompok-kelompok atau organisasi, mengarahkan perilaku mereka untuk mencapai tujuan, dan membantu menciptakan budaya kelompok atau organisasi; dan dari sudut kepemilikan, yang diartikan sebagai seperangkat ciri-ciri yang menjadi atribut seseorang yang dipersepsikan sebagai seorang pemimpin.

Jika dirujuk pada rangkaian definisi di atas, kepemimpinan pada dasarnya memiliki dua unsur yakni pengaruh dan pencapaian tujuan. Proses mempengaruhi dapat dimana saja selama tujuannya ada, dan tujuan tersebut merupakan tujuan bersama. Dengan demikian, kepemimpinan itu dapat terjadi setiap saat selama suatu kegiatan memiliki tujuan dan perilaku manusianya diarahkan untuk mencapai tujuan tersebut. Hal ini sesuai dengan pendapat Hersey dan Blanchard yang mengastakan, "Leadership occurs any time one attempts to influence the behavior of an individual or group, regardless of the reason".

Bender (1997), melihat kepemimpinan tidak hanya dari dimensi proses mempengaruhi dan mencapai tujuan, tetapi juga dari dimensi figur atau sifat kepemimpinan yang diperlukan pada masa yang akan datang. Ditegaskan bahwa pada masa yang akan datang pemimpin yang diperlukan adalah yang mampu mengantisipasi perubahan, dengan ciri-ciri: kepemimpinan itu menyangkut manusia (Leader-ship is about people); kepemimpinan merupakan upaya menjadikan diri sendiri menjadi pemimpin yang berarti (Leadership is about being the leader of you); kepemimpinan itu menyangkut motivasi dari dalam diri (Leadership is about internal motivation); kepemimpinan merupakan perjuangan untuk kesempurnaan, dan menyadari ketidak sempurnaan diri sendiri (Leadership is about striving for perfection, while accepting our imperfection); kepemimpinan terkait dengan perubahan (Leadership is about change); kepemimpinan menyangkut kepercayaan diri (Leadership is about having confidence); kepemimpinan terkait dengan pertumbuhan (Leadeship is about growth); kepemimpinan terkait kepemilikan daya (Leadership is about having energy); kepemimpinan terkait dengan penciptaan suatu pengalaman yang positif (Leadership is about creating a positive experience); kepemimpinan menyangkut menciptakan hasil-hasil (Leadership is about creating results); dan kepemimpinan terkait dengan pengurangan rasa takut dan meningkatkan harapan (Leadership is about reducing fear and increasing hope ).

Di samping hal-hal yang telah disebutkan sebelumnya, Hersey dan Blanchard agar lebih berhasil dalam mempengaruhi orang lain, seorang pemimpin harus memiliki tiga kompetensi dasar kepemimpinan, yakni kompetensi: mendiagnosis, mengadaptasi dan mengkomunikasikan. Kompetensi diagnosis merupakan kemampuan kognitif yang dapat memahami situasi saat sekarang dan apa yang diharapkan pada masa yang akan datang; Kompetensi mengadaptasi adalah kemampuan seseorang menyesuaikan perilakunya dengan lingkungannya; sedangkan kompetensi mengkomunikasikan terkait dengan kemampuan seseorang dalam menyampaikan pesan-pesannya agar dapat dipahami orang lain dengan baik dan jelas.

Studi terhadap kepemimpinan telah berkembang ke dalam tiga pendekatan, menurut George dan Jones yaitu pendekatan: sifat atau bawaan (traits); perilaku, dan kontigensi (situasional).

Pendekatan pertama didasarkan atas pandangan bahwa kepemimpinan merupakan seperangkat sifat atau bakat yang dimiliki individu yang membuat mereka mampu untuk memimpin. Sifat-sifat yang dimiliki seorang pemimpin, menurut Wexley dan Yukl (2001), adalah dapat beradaptasi terhadap segala situasi, peduli dengan lingkungan sosial, ambisius dan berorentasi pada prestasi, asertif, kooperatif, mampu membuat keputusan, memiliki ketergantungan, dominan (memiliki 
hasrat mempengaruhi orang lain), energik, penyabar, percaya diri, toleran terhadap tekanan, dan mau bertanggung jawab. Dari aspek keterampilannya, seorang pemimpin memiliki karakteristik cerdas, keterampilan konseptual, kreatif, diplomatis dan taktis, fasih berbicara, memiliki pengetahuan tentang tugas kelompoknya, memiliki kemampuan administratif, persuasif, dan memiliki keterampilan sosial.

Relevan dengan pendapat di atas, Newstrom dan Davis (2001) menyatakan ciri-ciri seorang pemimpin, dipandang dari sifatnya, adalah memiliki hasrat personal yang tinggi, hasrat untuk memimpin, integritas personal, dan rasa percaya diri. Dari sudut pandang keterampilannya, seorang pemimpin memiliki kemampuan kognitif, pengetahuan bisnis, karisma, kreativitas, fleksibilitas, dan kepribadian yang hangat.

Pendekatan kepemimpinan dari perspektif sifat atau bakat ini kurang mendapat sambutan dari kalangan akademisi atau peneliti lainnya karena kurang ilmiah. Kepemimpinan mulai dipelajari dalam konteks perilaku. Dalam pandangan ini, George dan Jones berpendapat kepemimpinan yang berhasil tergantung banyak pada perilaku, keterampilan, dan tindakan pemimpin itu sendiri dan mengabaikan aspek bakat atau sifat yang dimiliki pemimpinnya.

Kepemimpinan berperspektif perilaku ini pada dasarnya mempelajari kepemimpinan berdasarkan keterampilan yang dimiliki oleh seorang pemimpin. Keterampilan ini secara garis besarnya dapat dibagi ke dalam tiga kategori utama, yakni keterampilan teknik, manusiawi, dan konseptual. Keterampilan teknik terkait dengan pengetahuan dan kemampuan melakukan pekerjaan yang bersifat teknis; keterampilan manusiawi merupakan kemampuan bekerja secara efektif dengan orang-orang, membangun tim kerja dan ini merupakan bagian dari kepemimpinan berperspektif perilaku; keterampilan konseptual adalah kemampuan berpikir dalam bentuk modelmodel, kerangka kerja, dan hubungan yang luas lainnya.

Esensi teori kepemimpinan berperspektif perilaku ini terfokus pada sikap atau perasaan pemimpin untuk menerima atau menolak produksi atau manusia. Jika seorang pemimpin lebih menekankan perhatiannya pada aspek produksi, maka ia akan cenderung mengabaikan aspek manusianya, dan sebaliknya. Menurut Mullins ada lima teori yang mengkaji kepemimpinan dari perspektif perilaku ini. Teori-teori tersebut adalah Kajian Kepemimpinan Negara Ohio (Ohio State Leadership Studies); Kajian Kepemimpinan Michigan (Michigan Leadership Style); Kajian Dinamika Kelompok (Group Dynamics Studies); Sistem Manajemen Rensis Likert (Rensis Likert's Management Systems); dan Managerial Grid.

Pendekatan ketiga, pendekatan situasional - dibangun di atas asumsi bahwa tidak ada satu cara pun yang dapat mengarahkan manusia untuk bekerja pada semua situasi, Dengan demikian, seorang pemimpin harus memiliki perilaku yang fleksibel, mampu mendiagnosis gaya kepemimpinan yang sesuai dengan situasi yang dihadapinya, serta mampu menerapkannya dengan baik. Relevan dengan pendapat di atas, mengutip pendapat Vroom, Hersey dan Blanchard mengatakan, "I do not see any form of leadership as op-timal all situations. The contribution of a leader's action to the effectiveness of his organization cannot be determined without considering the nature of the situation in which that behavior is displayed" Untuk mendiagnosis dan menerapkan gaya kepemimpinan yang sesuai dengan situasi yang dihadapi, seorang pemimpin harus memperhatikan tiga faktor utama, yakni: Perhatian terhadap bawahan, yang berarti kepedulian pimpinan terhadap keahlian, pengalaman, kemampuan, pengetahuan tentang tugasnya, tingkat hierarkis, dan karakteristik psikologis bawahannya; Perhatian terhadap atasan $\_$yang mencerminkan derajat pelaksanaan pengaruhnya, ataupun ke-samaan sikap dan perilakunya pada orang-orang yang di atasnya; Perhatian terhadap tugas,mencerminkan derajat urgensi waktu yang dimiliki, bahaya fisik, rata-rata kesalahan yang diizinkan, derajat otonomi, luas skop pekerjaan, dan derajat kekaburan pelaksanaan tugas.

Beberapa teori yang termasuk ke dalam kepemimpinan berdimensi situasi ini dan mendapat perhatian yang besar dari banyak kalangan peneliti kepemimpinan adalah Teori Perilaku Pemimpin Tannenbaum-Schmidt (the Tannenbaum and Schmidt Continuum of Leader Behavior); Teori Contingency Fiedler (Fiedler's Con- 
tingency Model); Teori Jalur Tujuan House-Mitchell (the House - Mitchell Path - Goal Theory); Model Contingency Vroom-Yetten (Vroom-Yetten Contingency Model), dan Model Efektivitas Pemimpin Tiga Dimensi Hersey-Blanchard (Hersey-Blanchard TriDimensional Leader Effectiveness Model). Berdasarkan rangkaian teori di atas, maka gaya kepemimpinan yang dimaksudkan dalam hal ini dapat disintesiskan sebagai kesesuaian sikap dan perilaku dalam mempengaruhi pengikutnya yang terlihat dari; melakukan pendelegasian terhadap pengikut yang memiliki kemauan dan kemampuan; ikut serta melakukan pekerjaan jika pengikutnya kurang mampu, tetapi memiliki kemauan; menjual ide-ide terhadap pengikut yang pengikut yang memiliki kemampuan, tetapi tidak mempunyai kemauan; dan memerintah jika pengikutnya tidak memiliki kemampuan dan kemauan.

\section{Budaya Kerja}

Budaya kerja yang dimaksud dalam penelitian ini terkait dengan budaya kerja badan usaha pengadaan alat-alat pendidikan. Dengan demikian, konteks bahasannya terkait dengan budaya kerja perusahaan atau organisasi. Robbins menegaskan, budaya organisasi merupakan persepsi umum yang dianut oleh anggota organisasi atau suatu sistem dari pengertian bersama yang dimiliki oleh para anggotanya. Mengutip pendapat Schein, Luthans mendefinisikannya sebagai sebuah bentuk asumsi dasar yang ditemukan atau dikembangkan oleh sekelompok orang, dan dianggap cukup sehingga diajarkan kepada para anggota baru sebagai cara yang benar dalam mempersepsikan, berpikir, dan merasakan hubungan dengan masalah-masalah yang dihadapi organisasi. Kreitner dan Kinicki (2004) mendefinisikan budaya kerja perusahaan sebagai perekat sosial yang mengikat para anggota organisasi secara bersama-sama melalui nilai-nilai, simbul-simbul, dan cita-cita yang dianut bersama. Relevan dengan pendapat sebelumnya, George dan Jones mendefinisikan budaya kerja perusahaan sebagai seperangkat nilai-nilai dan norma-norma informal yang mengendalikan cara orang-orang atau kelompok dalam suatu organisasi melakukan interaksi satu sama lainnya di dalam dan di luar organisasi.
Berdasarkan definisi di atas, budaya kerja perusahaan dapat disimpulkan sebagai seperangkat nilai-nilai, norma-norma, asumsi, keyakinan dan sistem yang mengintegrasikan dan mengendalikan cara para anggotanya melakukan interaksi satu sama lain.

Kotter dan Heskett (1997) menegaskan bahwa dilihat dari sisi kejelasan dan ketahanannya terhadap perubahan, budaya kerja perusahaan dapat dibagi ke dalam dua tingkatan, yaitu: Tingkatan pertama, biasanya lebih dalam dan kurang terlihat, merupakan "nilai-nilai yang dianut bersama oleh orang dalam kelompok dan cenderung bertahan sepanjang waktu bahkan meskipun anggotanya sudah berubah". Tingkatan kedua, yang lebih terlihat, budaya kerja perusahaan menggambarkan "pola atau gaya perilaku suatu organisasi sehingga anggotaanggota baru secara otomatis terdorong untuk mengikuti sejawatnya".

Sesuai dengan pendapat tersebut, pada tingkatan pertama, budaya kerja perusahaan dapat dianggap sebagai kepribadian, atmosfir, atau "perasaan" suatu organisasi sehingga sukar diamati secara sepintas. Meskipun demikian, bukan berarti bahwa budaya kerja perusahaan tidak dapat dipelajari, namun akan menyita banyak waktu karena harus menyelami dan menghayati nilai-nilai yang ada dalam organisasi agar dapat "mengungkap" fenomena yang ada secara kasat mata.

Budaya kerja perusahaan tingkatan pertama ini, menurut Luthans (2001) dapat melalui aspekaspek; Filosofi dasar dari organisasi; Nilai-nilai yang mendasari norma-norma organisasi; Normanorma yang menjadi acuan perilaku; Status yang disepakati terhadap individu-individu tertentu; Aturan formal dan informal yang telah dikembangkan; dan Jenis bahasa yang digunakan dalam organisasi.

Pada tingkatan kedua, budaya kerja perusahaan ini terlihat dari pola-pola perilaku para anggota organisasinya. Pola-pola ini akan terlihat tatkala para anggota organisasi mengambil keputusan, melayani konsumen, berpakaian, dan sebagainya. Jika hampir semua anggota organisasi tidak dapat mengambil keputusan, maka budaya kerja perusahaan tersebut dapat dikategorikan sebagai budaya yang sangat lemah 
sehingga keputusan yang kecil sekali pun harus melibatkan para pimpinannya. Hal ini tentu saja akan menyita waktu dan tidak efisien. George dan Jones menjelaskan nilai-nilai yang terdapat dalam budaya kerja perusahaan meliputi: nilainilai terminal (terminal values), yaitu tujuan-tujuan yang berusaha dicapai suatu organisasi, seperti kesempurnaan, stabilitas, inovasi, moral dan kualitas dan nilai instrumental (instrumental values) atau semangat dan gaya perilaku organisasi yang dianjurkan, antara lain bekerja keras, kreatif, dan ambil risiko.

Griffin (1997) menegaskan bahwa budaya kerja perusahaan berbeda dengan iklim organisasi. Budaya kerja perusahaan berkaitan dengan sejarah dan tradisi organisasi yang menekankan pada nilai dan norma, sedangkan iklim organisasi berkaitan dengan suasana sekarang dalam suatu organisasi. Sistem nilai dapat berubah sesuai dengan perkembangan zaman, namun bagi sebahagian organisasi, sistem nilai ini selalu dijaga dan dikembangkan berdasarkan landasan yang telah dibangun sebelumnya. Tinggi rendahnya komitmen para anggota organisasi dalam menjaga dan mengembangkan sistem nilai ini akan mencerminkan kuat lemahnya budaya kerja perusahaan.

Kotter dan Hesket (1997)menegaskan budaya kerja perusahaan yang kuat ini tercermin dalam tingkat kekonsistenan para manajer atau anggota organisasi lainnya memegang teguh nilainilai dan metode kerja yang mereka bangun. Dengan demikian, tidak mustahil seorang bawahan dapat menegur atasannya jika pihak atasan ini keluar dari nilai-nilai atau metode cara kerja yang biasa mereka lakukan. Selanjutnya dijelaskan budaya kerja perusahaan yang kuat perlu dijaga dan dikembangkan karena dapat meningkatkan prestasi kerja anggota organisasi maupun organisasinya sendiri. Hal ini cukup beralasan sebab kondisi tersebut akan berfungsi menyatukan tujuan anggota organisasi; meningkatkan motivasi kerja para anggotanya, dan memberikan struktur dan kontrol yang ketat pada anggotanya tanpa harus bersandar pada aturan birokratis.

Relevan dengan pendapat di atas, Flaney, Hofrichter dan Platten (1996) menyatakan budaya kerja perusahaan laksana sebuah permainan olah raga dimana satu sama lain berkompetisi untuk memenangkan permainan. Pemenang permainan ini berhak atas sejumlah hadiah berupa mendapatkan promosi, bonus dan sejumlah aktivitas yang bersifat ritual lainnya.

Berbeda dengan pendapat di atas, Robbins menegaskan bahwa budaya kerja perusahaan yang kuat memiliki tujuh karakteristik, yaitu: Inovatif dan siap mengambil resiko. Organisasi yang memiliki budaya kuat memiliki derajat keinovatifan yang tinggi dan para anggotanya diberikan kesempatan melakukan eksperimen sesuai dengan visi organisasi tanpa perlu merasa kuatir akan risiko yang mereka dapatkan jika mengalami kegagalan; Perhatian pada hal-hal yang detail. Budaya kerja perusahaan kuat memiliki ciri-ciri yang selalu memperhatikan detail setiap kegiatan yang mereka lakukan; Berorientasi pada tujuan (outcome). Lembaga yang memiliki budaya yang kuat selalu berorientasi pada tujuan, bukan proses sehingga banyak alternatif yang mungkin dapat digali dan dikembangkan oleh anggotanya; Berorientasi pada orang, budaya kerja perusahaan yang kuat selalu mempertimbangkan tujuan yang akan dicapai dengan kemampuan SDM yang dimilikinya sehingga terkadang dapat dilihat dari frekuensi dan intensitas pengembangan SDMnya; Berorientasi pada tim, budaya kerja perusahaan yang kuat selalu mendisain aktivitas kerja para anggotanya berdasarkan kelompok yang ada dalam organisasi; Agresif, budaya kerja perusahaan yang kuat selalu menciptakan suasana kerja yang kompetitif dan membuat para anggotanya bersifat lebih agresif untuk menemukan hal-hal baru; Stabilitas, ciri ini ditandai dengan aktivitas organisasi menjaga status quonya secara relatif dalam menghadapi akselerasi pertumbuhan yang terjadi di lingkungannya.

Dibandingkan dengan pendapat sebelumnya, pendapat yang terakhir ini jauh lebih sederhana dan lebih bersifat operasional. Misalnya saja, istilah "agresif" pada pendapat yang pertama, dapat berkonotasi negatif, mengingat hal itu dapat diartikan "bisa menyerang orang lain". Dengan demikian, indikator yang akan digunakan dalam penelitian ini secara keseluruhan diadopsi dari pendapat yang terakhir tersebut. 
Kreitner dan Kinicki mengatakan bahwa budaya kerja perusahaan dipengaruhi oleh kondisi ekonomi, politik, latar belakang etnis dan agama. Dalam kondisi ekonomi dan politik yang stabil organisasi cenderung memelihara budaya yang kuat. Budaya kerja perusahaan yang kuat cenderung terlihat pada etnis dan agama yang lebih demokratis, dari pada budaya dan agama yang bersifat paternalistik.

Wagner III dan Hollenbeck (1992) menyimpulkan bahwa ada delapan elemen dalam budaya kerja perusahaan yaitu: Ceremonies, upacara atau kegiatan tertentu yang dilakukan oleh anggota organisasi yang menjadi simbol dari organisasi tersebut; Rites atau kegiatan-kegiatan atau upacara sebagai alat mengkomu-nikasikan ideide; Stories atau kejadian-kejadian lama yang membekas secara mendalam dan menjadi norma dan nilai; Myths, yakni hal-hal atau cerita-cerita yang dipercayai; Heroes, yakni kesuksesan seseorang yang merupakan pengejawantahan dari nilai; Superstars, yakni keistimewaan seseorang yang merupakan personifikasi keberhasilan yang dicapai organisasi; Symbols, yakni peristiwa penting yang dimungkinkan anggota organisasi tukar menukar ide (lambanglambang); Language, yakni bahasa yang biasa digunakan.

Elemen-elemen ini terintegrasi secara utuh dan menjadi kepribadian organisasi. Kumpulan elemen-elemen tersebut dapat dijadikan sebagai karakteristik yang membedakan kepribadian satu organisasi dengan organisasi lain. Kepribadian organisasi inilah yang menjadi elemen paling esensial dalam konteks budaya kerja perusahaan dan menjadi acuan bagi setiap anggotanya untuk berperilaku di dalam maupun di luar organisasi.

Flaney, Hofrichter dan Platten menyatakan bahwa budaya kerja perusahaan harus diimplementasikan sejak awal rekrutmen sampai pegawai mendapat masa pensiunannya. Hal ini tentu saja perlu diikuti dengan sistem penggajian yang lebih kompetitif.

Berdasarkan uraian tersebut di atas, maka dapat disintesiskan bahwa budaya kerja merupakan kebiasaan-kebisaan kerja yang sudah terpola dalam menekankan pada nilai dan norma yang mencakup: kepercayaan terhadap bawahan; keterbukaan komunikasi; kepemimpinan yang memperhatikan dan mendukung orang lain; pemecahaan masalah dengan tim; otonomi pekerja; ketersediaan akses informasi; dan keluaran dan tujuan yang tinggi.

\section{Efektivitas Organisasi}

Helms (2008) menegaskan efektivitas organisasi adalah organisasi yang mengerjakan semua hal yang harus dikerjakannya dan melaksanakan pekerjaan tersebut dengan benar. Griffin (1997) mendefiniskannya sebagai organisasi yang membuat keputusan-keputusan yang tepat dan berhasil mengimplementasikannya dengan baik. Robbins (1994) menyatakan efektivitas organisasi sebagai "sejauh mana organisasi dapat mewujudkan tujuan-tujuannya". Melengkapi definisi sebelumnya, Drucker (1997), menegaskan bahwa efektivitas organisasi terkait dengan organisasi yang membuat hal-hal yang tepat bisa terlaksana.

Dari rangkaian definisi di atas, efektivitas organisasi terkait dengan organisasi yang senantiasa dapat: mewujudkan tujuantujuannya; membuat keputusan-keputusan yang tepat; melaksanakan pekerjaan yang benar. Kriteria pertama menegaskan bahwa organisasi senantiasa memiliki tujuan yang harus dicapai. Menurut Simon (1997) hal ini bersifat mutlak karena dari definisinya saja organisasi adalah sekumpulan orang yang bekerja-sama untuk mencapai tujuan. Jika dikaji secara lebih mendalam, yang menyatukan sekelompok orang untuk bekerjasama, dalam wadah yang disebut organisasi, adalah tujuan ini. Kriteria kedua menegaskan bahwa sebagai konsekuensi logis untuk mewujudkan tujuannya, organisasi harus membuat keputusan-keputusan yang benar. Pembuatan keputusan inilah yang menjadi pekerjaan yang esensial sebuah organisasi. Menurut Collins (2001) hal ini dikarenakan bahwa anggota organisasi memiliki nilai-nilai yang berbeda satu sama lain dan lingkungannya senantiasa berubah secara dinamis. Agar tetap sejalan dengan dinamika lingkungannya, organisasi perlu dan senantiasa harus membuat keputusan untuk penyesuaiannya. Kriteria ketiga, terakhir, menegaskan bahwa keputusan yang telah diambil harus dikerjakan dengan benar agar keputusan yang telah dibuat dapat direalisasikan 
dan tidak menjadi monumen yang hanya ada dalam catatan atau imajinasi para anggotanya.

Menurut Simon (1997), tujuan sebuah organisasi bukan merupakan hal yang bersifat statis, melainkan harus senantiasa menyesuaikan diri dengan kebutuhan pelanggannya. Pernyataan tersebut bukan tanpa alasan. Organisasi tidak akan dapat bertahan lama jika tidak mampu memenuhi kebutuhan para pelanggannya, baik internal maupun eksternal, karena mereka iniliah yang menjadi penopang utama berdirinya sebuah organisasi. Menurut Sallis (1999) pelanggan internal sebuah organisasi adalah anggota organisasi, sedangkan pelanggan eksternalnya adalah pemangku kepentingan dalam organisasi tersebut, baik pelanggan dalam arti yang sebenarnya, maupun pemilik modal. Kedua jenis pelanggan inilah yang membuat organisasi tetap bertahan meskipun dinamika lingkungannya berjalan dengan sangat cepat. Jika kebutuhan para pe-langgan internal atau anggota organisasi tidak terpenuhi, maka mereka akan berpotensi keluar dan berpotensi mengancam keberadaan organisasi tersebut. Hal yang sama juga terhadap pelanggan eksternal. Jika kebutuhan mereka tidak dapat dipenuhi telah organisasi, maka kontribusi mereka terhadap organisasi tersebut akan berkurang atau hilang sehingga dapat memperlemah posisi organisasi tersebut. Dengan demikian, organisasi yang efektif senantiasa memiliki tujuan-tujuan yang dinamis.

Pendapat yang terakhir ini juga diperkuat oleh Inamori (1997) yang menegaskan bahwa masyarakat ibarat hutan besar di sekitar perusahaan. Di dalam hutan tersebut terdapat investor, yang menyediakan modal; pemasok, yang menyediakan suku cadang atau material; dan konsumen, yang membeli produk. Dengan demikian, setiap korporat harus memanfaatkan potensi ini dengan senantiasa mengadopsi kebutuhan mereka ke dalam tujuan organisasinya. Jika tujuan organisasi tidak sesuai dengan kebutuhan mereka, tidak mustahil salah satu elemen ini akan hilang yang membuat organisasi akan kehilangan daya hidup. Konsekuensinya, eksistensi organisasi tersebut tidak akan terancam yang berarti bahwa organisasi tersebut akan kehilangan efektivitasnya.
Untuk mendukung pencapaian tujuan yang dinamis ini, organisasi memerlukan anggotaanggota organisasi yang tepat. Hal ini sejalan dengan pendapat Collins (2001) yang menegaskan bahwa orang bukanlah merupakan asset organisasi yang paling penting, tetapi orang yang tepatlah yang sesungguhnya merupakan asset organisasi yang paling penting. Selanjutnya ditambahkan bahwa jika organisasi memiliki orang yang tepat, maka; organisasi tersebut akan mudah menyesuaikan diri dengan dunia yang sedang berubah ini; masalah memotivasi dan mengelola mereka tidak lagi memerlukan energi yang besar; dan tanpa dukungan orang yang tepat, organisasi tidak akan dapat mencapai visinya.

Menurut Nadler dan Michael L. Tushman (2001) telah ditegaskan sebelumnya bahwa organisasi yang efektif merupakan organisasai yang memiliki tujuan-tujuan yang dinamis sejalan dengan dinamika lingkungannya. Hal ini berarti bahwa organisasi yang efektif merupakan sebuah sistem yang terbuka yang mentransformasikan masukan dari lingkungannya menjadi berbagai macam keluaran yang dibutuhkan lingkungannya. Sebagai sebuah sistem terbuka, di dalam organisasi terjadi tarik menarik empat komponen: manusia: pekerjaan; organisasi formal; dan organisasi informal. Agar hal ini tidak menjadi faktor penghambat organisasi dalam mencapai tujuannya, maka perlu dibuat disain organisasi yang menjadi acuan setiap anggota organisasi untuk bertindak. Desain organisasi yang tepat akan menentukan efektivitas organisasi tersebut, tidak hanya dalam mencapai tujuannya, tetapi juga dalam memelihara anggota organisasinya dan mendorong mereka untuk mencapai tujuan yang lebih besar.

Berdasarkan uraian di atas, dapat disintesiskan bahwa efektivitas organisasi adalah suatu kondisi yang memungkinkan organisasi dapat mengerjakan semua hal yang harus dikerjakannya dan melaksanakan pekerjaan tersebut dengan benar melalui pemanfaatan sumber daya yang optimal demi mencapai tujuan yang telah ditentukan dengan indikator: memiliki tujuan yang dinamis; memiliki sasaran yang terukur; memiliki kebijakan yang visioner; memiliki anggota organisasi yang mampu mewujudkan 
tujuan organisasi; dan memiliki disain organisasi yang mampu mendorong pencapaian tujuan organisasi.

\section{Kerangka Berpikir}

\section{Pengaruh Langsung Kekohesifan terhadap Budaya Kerja}

Berdasarkan uraian sebelumnya, kekohesifan adalah keterikatan antaranggota untuk bekerjasama yang ditandai dengan adanya: adanya saling pengertian; kerjasama, saling berbagi pengetahuan, dan menampilkan perilaku yang diharapkan anggota kelompoknya.

Pada sisi lain, budaya kerja merupakan kebiasaan-kebisaan kerja yang sudah terpola dengan menekankan pada nilai dan norma yang mencakup: kepercayaan terhadap bawahan; keterbukaan komunikasi; kepemimpinan yang memperhatikan dan mendukung orang lain; pemecahaan masalah dengan tim; otonomi pekerja; ketersediaan akses informasi; dan keluaran dan tujuan yang tinggi.

Jika sebuah perusahaan memiliki kelompok kerja yang kohesif, maka hubungan antara pegawai dengan pegawai lainnya atau pegawai dengan atasannya akan lebih erat. Hal ini membuat mereka merasa dalam satu keluarga besar sehingga dapat memecahkan masalahmasalah yang mereka hadapi secara bersamasama. Dalam konteks inilah akan timbul saling percaya dan saling menghargai sehingga komunikasi antara mereka akan makin terbuka yang lama-kelamaan akan menjadi sebuah kebiasaan. Ciri-ciri yang terakhir ini merupakan gambaran sebuah budaya kerja. Berdasarkan argumentasi di atas, dapat diduga bahwa terdapat pengaruh langsung kekohesifan terhadap budaya kerja.

\section{Pengaruh Langsung Kekohesifan terhadap Efektivitas Organisasi}

Kekohesifan adalah keterikatan antar anggota untuk bekerjasama, sedangkan efektivitas organisasi adalah suatu kondisi yang memungkinkan organisasi dapat mengerjakan semua hal yang harus dikerjakannya dan melaksanakan pekerjaan tersebut dengan benar demi mencapai tujuan yang lebih besar dengan indikator: memiliki tujuan yang dinamis; memiliki anggota organisasi yang mampu mewujudkan tujuan organisasi; dan memiliki disain organisasi yang mampu mendorong pencapaian tujuan organisasi.

Jika anggota organisasi sudah terikat secara utuh dalam organisasi, mereka akan terpacu untuk bekerja lebih keras sehingga hasil kerja mereka tidak akan sia-sia jika dibawa ke lingkungannya. Hal ini menandaskan bahwa mereka berhasil membawa organisasinya mengikuti dinamika lingkungannya. Kondisi yang terakhir ini merupakan indikator dari sebuah organisasi yang efektif.

Berdasarkan argumentasi ini dapat diduga bahwa terdapat pengaruh langsung kekohesifan terhadap efektivitas organisasi

\section{Pengaruh Langsung Gaya Kepemimpinan terhadap Budaya Kerja}

Gaya kepemimpinan adalah kesesuaian sikap dan perilaku dalam mempengaruhi pengikutnya yang terlihat dari: melakukan pendelegasian; ikut serta melakukan pekerjaan; menjual ide-ide terhadap pengikut; dan memerintah jika diperlukan.

Pada sisi lain, budaya kerja merupakan kebiasaan-kebisaan kerja yang menekankan pada nilai dan norma yang mencakup: kepercayaan terhadap bawahan; keterbukaan komunikasi; kepemimpinan yang memperhatikan dan mendukung orang lain; pemecahaan masalah dengan tim; otonomi pekerja; ketersediaan akses informasi; dan keluaran dan tujuan yang tinggi.

Ciri kepemimpinan yang efektif adalah mempercayai pengikutnya sehingga bagi pengikut yang yang telah mampu dan memiliki kemauan diberikan otonomi, sedangkan pengikut yang belum matang senantiasa dibina dengan melakukan komunikasi yang terbuka. Hal yang terakhir ini merupakan unsur yang esensial budaya organisasi. Berdasarkan argumentasi ini dapat diduga bahwa terdapat pengaruh langsung gaya kepemimpinan terhadap budaya kerja.

\section{Pengaruh Langsung Gaya Kepemimpinan terhadap Efektivitas Organisasi}

Seperti telah diuraikan sebelumnya, gaya kepemimpinan merupakan kesesuaian sikap dan perilaku dalam mempengaruhi pengikutnya, 
sedangkan efektivitas organisasi adalah suatu kondisi yang memungkinkan organisasi dapat mengerjakan semua hal yang harus dikerjakannya dan melaksanakan pekerjaan tersebut dengan benar demi mencapai tujuan yang lebih besar dengan indikator: memiliki tujuan yang dinamis; memiliki anggota organisasi yang mampu mewujudkan tujuan organisasi; dan memiliki disain organisasi yang mampu mendorong pencapaian tujuan organisasi.

Kondisi yang mampu mewujudkan tujuan organisasi senantiasa memerlukan dorongan. Dorongan ini muncul jika dilaksanakan sesuai dengan kebutuhan dan kematangan pengikut. Di sinilah keterkaitan antara gaya kepemimpinan dan efektivitas organisasi. Berdasarkan argumentasi ini dapat diduga bahwa terdapat pengaruh langsung gaya kepemimpinan terhadap efektivitas organisasi.

\section{Pengaruh Budaya Kerja terhadap Efektivitas Organisasi}

Budaya kerja merupakan kebiasaan-kebisaan kerja yang yang sudah terpola yang menekankan pada nilai dan norma, sedangkan efektivitas organisasi adalah suatu kondisi yang memungkinkan organisasi dapat mengerjakan semua hal yang harus dikerjakannya dan melaksanakan pekerjaan tersebut dengan benar demi mencapai tujuan yang lebih besar.

Salah satu prasyarat untuk mencapai tujuan yang lebih besar adalah adanya kerjasama dan komunikasi yang terbuka. Hal ini hanya dapat dibangun melalui budaya kerja yang kuat.

Berdasarkan argumentasi ini dapat diduga bahwa terdapat pengaruh langsung budaya kerja terhadap efektivitas organisasi.

\section{Pengaruh tidak langsung Kekohesifan terhadap efektivitas Organisasi melalui Budaya Kerja}

Seperti telah diuraikan sebelumnya, kekohesifan diduga berpengaruh terhadap budaya kerja, dan selanjutnya berpengaruh juga terhadap efektivitas organisasi. Selanjutnya, budaya kerja juga diduga berpengaruh terhadap efektivitas organisasi. Kondisi ini membuat posisi budaya kerja sebagai suatu terminal bagi kekohesifan untuk membentuk efektivitas organisasi. Jika kerangka berpikir tersebut dapat diterima, maka dapat juga diduga bahwa kekohesifan berpengaruh tidak langsung terhadap efektivitas organisasi melalui budaya kerja.

\section{Pengaruh Tidak Langsung Gaya Kepemimpinan terhadap Efektivitas Organisasi melalui Budaya Kerja}

Pada bagian sebelumnya telah dijelaskan kerangka logis hubungan antara gaya kepemimpinan dengan budaya kerja korporat, dan efektivitas organisasi. Dalam kerangka berpikir tersebut, budaya kerja korporat menempati posisi antara gaya kepemimpinan dengan efektivitas organisasi. Kondisi ini membuat posisi budaya kerja korporat sebagai pihak yang menjembatani antara gaya kepemimpinan dengan efektivitas organisasi. Jika kerangka berpikir tersebut dapat diterima, maka dapat juga diduga bahwa gaya kepemimpinan berpengaruh tidak langsung terhadap efektivitas organisasi melalui budaya kerja korporat .

\section{Hipotesis}

Berdasarkan kajian teoretik dan kerangka berpikir sebagaimana dikemukakan sebelumnya, maka dapat diajukan hipotesis penelitian sebagai berikut. Pertama, terdapat pengaruh langsung kekohesifan terhadap budaya kerja. Kedua, terdapat pengaruh langsung kekohesifan terhadap efektivitas organisasi. Ketiga, terdapat pengaruh langsung gaya kepemimpinan terhadap budaya kerja, Keempat, terdapat pengaruh langsung gaya kepemimpinan terhadap efektivitas organisasi. Kelima, terdapat pengaruh langsung budaya kerja terhadap efektivitas organisasi. Keenam, terdapat pengaruh tidak langsung kekohesifan terhadap efektivitas organisasi melalui budaya kerja. Ketujuh, terdapat pengaruh tidak langsung gaya kepemimpinan terhadap efek-tivitas organisasi melalui budaya kerja.

\section{Metodologi Penelitian}

Penelitian ini dilakukan terhadap Badan Usaha pengadaan alat-alat pendidikan yang bersertifikasi dan terdaftar di KADIN. Penelitian dilakukan selama dilaksanakan selama dua bulan, yang dimulai pada akhir bulan April 2009 dan selesai pada akhir bulan Juni 2009. 
Penelitian ini dilakukan dengan metode survei dengan menggunakan analisas jalur (Path Analysis), dimana hubungan kausal dilakukan untuk menguji pengaruh langsung maupun tidak langsung Kekohesifan, Gaya Kepemimpinan, Budaya Kerja terhadap efektivitas organisasi Perusahaan Pengadaan Alat-alat Teknis Pendidikan di Jakarta. .

Penelitian ini bertujuan untuk mengetahui dan membuktikan ada tidaknya: pengaruh langsung kekohesifan terhadap budaya kerja; pengaruh langsung gaya kepemimpinan tehadap budaya kerja, pengaruh langsung kekohesifan terhadap efektivitas organisasi; pengaruh langsung gaya kepemimpinan terhadap efektivitas organisasi; pengaruh langsung budaya kerja terhadap efektivitas organisasi; pengaruh tidak langsung kekohesifan terhadap efektivitas organisasi melalui budaya kerja; pengaruh tidak langsung gaya kepemimpinan terhadap efektivitas organisasi melalui budaya kerja.

Sesuai dengan uraian di atas, model analisis jalur yang akan digali dalam penelitian ini dapat digambarkan sebagai berikut. diujicobakan untuk menilai validitas dan reliabilitasnya. Pengukuran validitas butir instrumen menggunakan rumus korelasi product moment. Hasil ujicoba memperlihatkan bahwa reliabilitas kuesioner kekohesifan $=0,914$; gaya kepemimpinan $=0,906$; reliabilitas budaya kerja $=0,926$; reliabilitas kuesioner efektivitas organisasi $=0,942$. Sesuai dengan hasil perhitungan tersebut, keseluruhan instrumen penelitian ini adalah sangat reliable dan layak digunakan untuk menjaring data penelitian.

\section{Hasil Penelitian}

Hasil penelitian ini menemukan bahwa:

Pertama, pengaruh langsung kekohesifan terhadap budaya kerja ditunjukkan melalui koefisien jalur $\left(\rho_{31}\right)=0,350$ dan terbukti sangat signifikan. Temuan menegaskan bahwa kekohesifan $\left(X_{1}\right)$ berpengaruh langsung terhadap budaya kerja $\left(\mathrm{X}_{3}\right)$. Dengan kata lain,

Kedua, pengaruh langsung gaya kepemimpinan terhadap budaya kerja ditunjukkan melalui harga koefisien jalur $\left(\rho_{32}\right)=0,498$ dan

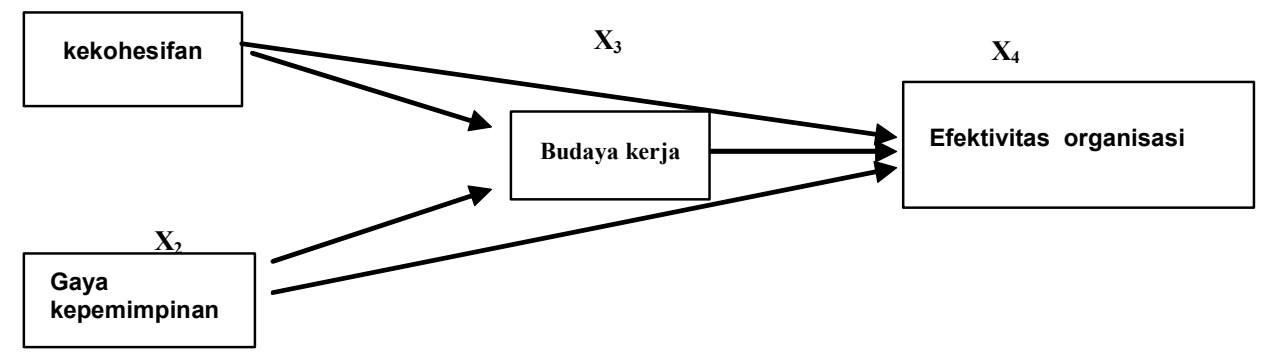

Populasi penelitian ini adalah perusahaan (korporat) yang berstatus Badan Usaha yang bersertifikasi dan terdaftar di KADIN Jakarta Pusat - Kerangka sampelnya adalah Badan Usaha yang berlokasi di DKI Jakarta yang berjumlah 120 perusahaan. Sampel ditetapkan sebanyak satu orang direktur dari level direktur yang dianggap membawahi perusahaan secara menyeluruh, untuk masing-masing perusahaan yang ditarik sebagai sampel. Perusahaan yang ditarik menjadi sampel adalah 30 perusahaan yang diambil dengan menggunakan teknik simple random sampling.

Untuk menjaring data, penelitian ini menggunakan instrumen berupa kuesioner yang dikembangkan sendiri oleh peneliti dan telah terbukti sangat signifikan. Temuan menegaskan bahwa gaya kepemimpinan $\left(X_{2}\right)$ berpengaruh langsung terhadap budaya kerja (x3). Dengan kata lain makin kuat gaya kepemimpinan, makin tinggi budaya kerja.

Ketiga, pengaruh langsung kekohesifan terhadap efektivitas organisasi diketahui melalui harga koefisien jalur $\left(\rho_{41}\right)=0,365$ dan terbukti sangat signifikan. Temuan menegaskan bahwa kekohesifan $\left(\mathrm{X}_{1}\right)$ berpengaruh langsung terhadap efektivitas organisasi $\left(X_{4}\right)$. Dengan kata lain, makin tinggi kekohesifan, makin tinggi efektivitas organisasi.

Keempat, pengaruh langsung gaya kepemimpinan terhadap efektivitas organisasi ditunjukkan melalui harga koefisien jalur $\left(\rho_{42}\right)=$ 
0,268 yang terbukti sangat signifikan. Temuan menegaskan bahwa gaya kepemimpinan $\left(X_{2}\right)$ berpengaruh langsung terhadap efektivitas organisasi $\left(\mathrm{X}_{4}\right)$. Dengan kata lain, makin tinggi gaya kepemimpinan, makin tinggi efektivitas organisasi.

Kelima, pengaruh langsung budaya kerja terhadap efektivitas organisasi ditunjukkan melalui harga koefisien jalur $\left(\rho_{43}\right)=0,341$ yang terbukti sangat signifikan. Temuan menegaskan bahwa budaya kerja $\left(\mathrm{X}_{3}\right)$ berpengaruh langsung terhadap efektivitas organisasi $\left(\mathrm{X}_{4}\right)$. Dengan kata lain, makin tinggi budaya kerja, makin tinggi efektivitas organisasi.

Keenam, pengaruh tidak langsung kekohesifan terhadap efektivitas organisasi melalui budaya kerja $r 31 \times r 43=0,35 \times 0,341=0,119$ yang terbukti sangat signifikan. Dengan kata lain, makin tinggi kekohesifan makin tinggi efektivitas organisasi melalui budaya kerja.

Ketujuh, pengaruh tidak langsung gaya kepemimpinan terhadap efektivitas organisasi melalui budaya kerja $r 32 \times r 43=0,498 \times 0,341$ $=0,195$ yang terbukti sangat signifikan. Dengan kata lain, makin tinggi gaya kepemimpinan makin tinggi efektivitas organisasi melalui budaya kerja. Temuan penelitian ini dapat dirangkum sebagai berikut.

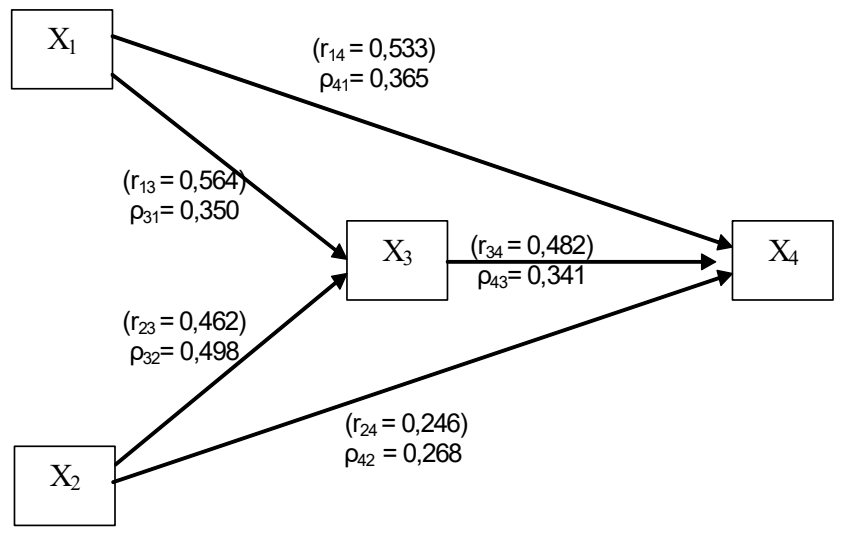

\section{Simpulan dan Saran}

Berdasarkan temuan penelitian di atas, dapat disimpulkan bahwa, kekohesifan, gaya kepemimpinan, budaya kerja merupakan varian dari efektivitas organisasi. Dengan demikian, upaya meningkatkan efektivitas organisasi dapat dilakukan dengan meningkatkan kekohesifan karyawan, memperkuat gaya kepemimpinan dan memperkuat budaya kerja.
Berdasarkan hasil perhitungan statistik temuan penelitian dapat diuraikan sebagai berikut. Pertama, terdapat pengaruh positif langsung dan signifikan kekohesifan terhadap budaya kerja. Dengan kata lain, makin tinggi kekohesifan, makin kuat budaya kerja. Kedua, terdapat pengaruh positif langsung kekohesifan terhadap efektivitas organisasi. Dengan kata lain, makin tinggi kekohesifan, makin efektif organisasi. Ketiga, terdapat pengaruh positif langsung gaya kepemimpinan terhadap budaya kerja. Dengan kata lain, makin efektif gaya kepemimpinan, makin kuat budaya kerja. Keempat, terdapat pengaruh positif langsung gaya kepemimpinan terhadap efek-tivitas organisasi. Dengan kata lain, makin efektif gaya kepemimpinan, makin efektif organisasinya. Kelima, terdapat pengaruh positif langsung budaya kerja terhadap efektivitas organisasi. Dengan kata lain makin kuat budaya kerja, makin efektif organisasi. Dari tiga variabel yang diteliti dan seluruhnya berpengaruh terhadap efektivitas organisasi dan ketiganya merupakan varians dari efektivitas organisasi, yakni: kekohesifan, gaya kepemimpinan dan budaya kerja. Sebagai konsekuensi, dapat juga disimpulkan bahwa: Keenam, terdapat pengaruh positif tidak langsung kekohesifan terhadap efektivitas organisasi melalui budaya kerja. Dengan kata lain, makin tinggi kekohesifan,makin kuat budaya kerja dan berimplikasi terhadap makin efektivnya organisasi. Ketujuh, terdapat pengaruh positif tidak langsung gaya kepemimpinan terhadap efektivitas organisasi melalui budaya kerja. Dengan kata lain makin kuat gaya kepemimpinan makin kuat budaya kerja dan berimplikasi makin efektifnya organisasi

Berdasarkan temuan penelitian di atas, dapat disimpulkan bahwa efektivitas organisasi dapat dibangun melalui interaksi antara kekohesifan, gaya kepemimpinan dan budaya kerja. Dan dapat diartikan bahwa kekohesifan, gaya kepemimpinan dan budaya kerja adalah merupakan varians dari efektivitas organisasi.

\section{Saran}

Berdasarkan kesimpulan yang telah diuraikan sebelumnya, saran-saran penelitian ini dapat diuraikan sebagai berikut: 
Badan Usaha Pengadaan Alat Teknis Pendidikan disarankan agar mengembangkan produknya kepada pembuatan spesifik alat-alat peraga yang berkualitas daripada menjadi penyalur alat peraga, sistem manajemen yang profesional, para pimpinan Badan Usaha Pengadaan Alat Teknis pendidikan perlu membangun satu divisi atau unit kerja khusus yang bertugas melaksanakan efektivitas organisasi dan mendorong agar unit kerja ini untuk bekerjasama dengan Lembaga sosial masyarakat dan perguruan tinggi agar hasil yang akan dicapai dapat lebih efektif, membuat program kerja berdasarkan kelompok yang terkait dengan sasaran organisasi, strategi pencapainnya dan metode evaluasi hasil sehingga dapat memacu penguatan budaya organisasi dan kekohesifan para karyawan, pada jajaran pimpinan masingmasing unit di organisasi. Badan Usaha Pengadaan Alat Teknis Pendidikan perlu menyusun pola komunikasi dan penjenjangan muatan tugas beserta kompensasinya agar lebih baik dan adil dalam rangka penguatan budaya kerja dan kekohesifan karyawan, para pimpinan unit bersama-sama direksi senantiasa melakukan dialog dengan para anggota karyawan dan organisasi lainnya, juga dibuat pembinaan anggota yang dapat memperkuat kepemimpinan, budaya kerja serta meningkatkan kekohesifan anggota organisasi dalam rangka meningkatkan efektivitas organisasi, bagi para peneliti lain disarankan pula untuk mengkaji faktor-faktor lain yang terkait dengan efektivitas organisasi dalam rangka meningkatkan citra positip Badan Usaha termaksud sebagai badan usaha yang peduli dan turut aktif dalam meningkatkan tingkat kemampuan dan keakhlian pemuda-pemudi bangsa Indonesia pada umumnya, Juga dengan kepemimpinan demokratis dan terpimpin menciptakan kesegaran bagi para karyawan dalam bekerja dan berkarya.

\section{Pustaka Acuan}

Bender, Peter Urs. 1997. Leadership From Within. Canada: Stoddart Publishing.

Collins, Jim. 2001. Good to Great. New York: Harper Collins.

Colquitt, Jason A., Jeffery A. Lepine \& Michael J. Wesson. 2009. Organizational Behavior. New York: McGraw-Hill, Inc.

Drucker, Peter F. 1997. The Effective Executive, terjemahan Agus Teguh Handoyo. Jakarta: Elex media Komputindo.

Flaney, Thomas P., David A. Hofrichter, Paul E. Platten. 1996. People, Performance, and Pay. New York: Free Press.

Franzoi, Stephen L. 1996. Social Psychology. Madison: Brown and Benchmark.

George, Jennifer M. \& Gareth R. Jones. 2002. Organizational Behavior. New Jersey: Prentice-Hall.

Griffin, Ricky W. 1997. Management. New Delhi: Houghton Miffin Company.

Hersey, Paul \& Kenneth H. Blanchard. 2001. Organization Human Behavior. New Jersey: Prentice Hall. Inamori, Kazuo. 1997. For People and For Profit. Tokyo: Kodansha International Ltd.

Kotter, John P. \& James L. Hesket. 1997. Corporate Culture and Performance, terjemahan Benyamin Molan. Jakarta: PT. Prenhallindo.

Kreitner, Robert \& Angelo Kinicki. 2004. Organizational Behavior. Boston: Richard D. IRWIN, Inc.

Luthans, Fred. 2001. Organizational Behavior. New York: McGraw-Hill, Inc.

McShane, Steven L. \& Mary Ann Von Glinow. 2005. Organizational Behavior. Boston: McGraw-Hill.

Mullins, Laurie J. 2005. Management and Organisational Behaviour. New Jersey: Prentice-Hall.

Nadler, David A. \& Michael L. Tushman, "The Organization of the Future: Strategic Imperative and Core Competencies for $21^{\text {st }}$ Century", dalam Joice S. Osland, David A. Kolb \& Irwin M. Rubin .eds 2001 The Organizational Behavior. New Jersey: Prentice-Hall, 
Newstrom, John W. \& Keith Davis. 2001. Organizational Behavior: Hill Human Behavior at Work. New Delhi, Tata McGraw- Publishing Co. Ltd.

Robbins, Stephen P. 2000. Organizational Behavior. New Jersey: Prentice-Hall International, Inc., Robbins, Stephen P. 1997. Managing Today. New Jersey: Prentice Hall, Sallis, Edward. 1999. Total Quality Management in Education. London: Harper Collins.

Simon, Herbert A. 1997. Administrative Behavior. New York: The Free Press, Undang-Undang Nomor 20 Tahun 2003. Tentang Sistim Pendidikan Nasional.

Wagner III, John A. \& John R. Hollenbeck. 1992. Management of Organizational Behavior. New Jersey: Prentice- Hall, Inc..

Wexley, Kenneth N. \& Gary A. Yukl. 2001. Organizational Behavior and Personnel Psychology. Illinois: Richard D. Irwin, Inc.. 